DOI 10.15290/cnisk.2020.02.09.08

JOLANTA CHWASTYK-KOWALCZYK

https://orcid.org/0000-0002-3463-6432

Uniwersytet Jana Kochanowskiego w Kielcach

\title{
Prasa jako źródło do badań działalności kobiet. Wybrane przykłady polskich dziennikarek emigracyjnych ${ }^{1}$
}

\section{Streszczenie}

Artykuł powstał na podstawie analizy zawartości opiniotwórczego czasopisma dla inteligencji „Nowy Czas. The New Time” wydawanego w Londynie w latach 2006-2018, po jego zawieszeniu. Ukazuje dziennikarskie i pozadziennikarskie działania Teresy Bazarnik-Małkiewicz, która wraz z mężem Grzegorzem Małkiewiczem (redaktorem naczelnym) jest współwłaścicielem periodyku. Łamy tego czasopisma najlepiej ukazuja jej dokonania w sferze inicjatyw pro publico bono oraz kreowanie wizerunku „Nowego Czasu” poprzez działania w zakresie public relations. Zainteresowana jest przede wszystkim kwestiami najszerzej pojętej kultury, edukacji wszystkich szczebli i dziennikarstwem interwencyjno-śledczym w kontekście życia Polaków w Zjednoczonym Królestwie.

Słowa kluczowe: „Nowy Czas. The New Time” 2006-2018, Teresa Bazarnik-Małkiewicz, Londyn, „ARTeria” 2009-2013, Fawley Court

1 Publikacja finansowana w ramach programu Ministra Nauki i Szkolnictwa Wyższego pod nazwa DIALOG w latach 2019-2021. Jest wynikiem udziału w projekcie badawczym pt. „Ośrodek badań historii kobiet”, nr 0016/DLG/2019/10. 


\title{
PRESS AS A SOURCE FOR RESEARCH ON WOMEN'S ACTIVITIES. SELECTED EXAMPLES OF POLISH ÉMIGRÉ FEMALE JOURNALISTS
}

\begin{abstract}
The article was based on the content analysis of the opinion-forming magazine for the intelligentsia, "Nowy Czas. The New Time", edited in London in 2006-2018, after its suspension. It shows the journalistic and non-journalistic activities of Teresa Bazarnik-Małkiewicz who, together with her husband Grzegorz Małkiewicz (editor-in-chief), co-owns the periodical. The pages of this periodical clearly expose her achievements in the field of pro publico bono initiatives and creating the image of "Nowy Czas" through public relations activities. She is primarily interested in broadly defined culture, education at all levels, as well as intervention and investigative journalism in the context of Polish life in the United Kingdom.

Keywords: "Nowy Czas. The New Time" 2006-2018, Teresa Bazarnik-Małkiewicz, London, “ARTeria” 2009-2013, Fawley Court
\end{abstract}

Czasopisma emigracyjne od momentu powstania do dnia dzisiejszego na całym świecie, będąc kroniką dokonań Polaków na obczyźnie, maja już ugruntowana pozycję jako źródło do badań nad historia naszej diaspory. Przykładem moga być opracowania naukowe Jolanty Chwastyk-Kowalczyk, Rafała Habielskiego, Żanety Steffek, Magdaleny Górki i innych ${ }^{2}$. Należy jednak pamiętać, że informacje zawarte w do-

2 Przykładowo: Jolanta Chwastyk-Kowalczyk, Londyński „Dziennik Polski” 1940-1943, (Kielce : Wydawnictwo Akademii Świętokrzyskiej, 2005); eadem, Londyński „Dziennik Polski i Dziennik Żolnierza” 1944-1989. Gazeta codzienna jako środek przekazu komunikatów kulturowych, (Kielce : Wydawnictwo Uniwersytetu Humanistyczno-Przyrodniczego Jana Kochanowskiego, 2008); eadem: Katyń, dipisi, PKPR na łamach polskich czasopism uchodźczych, (Kielce : Wydawnictwo Uniwersytetu Humanistyczno-Przyrodniczego Jana Kochanowskiego, 2011); eadem, Obraz Polaków na obczyźnie na łamach czasopism emigracyjnych, (Kielce : Wydawnictwo Uniwersytetu Jana Kochanowskiego, 2014); eadem, „Technika i Nauka” - elitarne czasopismo Stowarzyszenia Techników Polskich w Wielkiej Brytanii, (Kielce : Wydawnictwo Uniwersytetu Jana Kochanowskiego, 2015); eadem, Londyński „Nowy Czas” na początku XXI wieku, (Kielce : Wydawnictwo Uniwersytetu Jana Kochanowskiego, 2019); eadem, Londyński „Pamiętnik Literacki” - organ Zwiazku Pisarzy Polskich na Obczyźnie w latach 1976-2018, (Kielce : Wydawnictwo Uniwersytetu Jana Kochanowskiego, 2019); Rafał Habielski, Niezłomni i nieprzejednani. Emigracyjne „Wiadomości” i ich krag 1940-1981, (Warszawa : Państwowy Instytut Wydawniczy, 1991); idem, „Prasa w okresie II wojny światowej. Prasa emigracyjna po 1945 roku”, w: Prasa, radio 
niesieniach prasowych zawsze wymagają konfrontacji z innymi źródłami, także $z$ uwagi na częste błędy pojawiające się na łamach czasopism w postaci literówek, nieprawidłowych nazw własnych - miejscowości, nazwisk, pseudonimów itd., wynikających $z$ braku profesjonalizmu redakcji. Zasadnicza kwestia jest konieczność krytycznego podejścia do prezentowanych w prasie poglądów politycznych, zatajania niektórych faktów, pomijania innych czy eksponowania takich, jakich oczekuje właściciel danego tytułu. Pomimo tych zastrzeżeń medioznawcy wiedza, że czasopisma sa miejscem dokumentowania bieżącego życia i działalności diaspory, które sa nie do przecenienia, bowiem to tu często odnajdujemy jedyne odnotowania różnych zjawisk i przejawów zaistnienia uczestników opisywanych wydarzeń.

Artykuł powstał na podstawie analizy zawartości opiniotwórczego czasopisma dla inteligencji „Nowy Czas. The New Time” edytowanego w Londynie od 2006 do 2018 r., kiedy zostało zawieszone. Ukazuje dziennikarskie i pozadziennikarskie działania Teresy Bazarnik-Małkiewicz, która jest wraz z mężem Grzegorzem Małkiewiczem (redaktorem naczelnym) współwłaścicielem periodyku. Łamy tego czasopisma najlepiej ukazuja jej dokonania w sferze inicjatyw pro publico bono oraz kreowanie wizerunku poprzez działania w zakresie public relations.

W komunikacie nadesłanym przez Zarząd Zrzeszenia Plastyków Polskich w Wielkiej Brytanii do redakcji „Kontynentów. Nowego Merkuriusza" w Londynie pod koniec lat 50 . XX w. czytamy:

Im dłużej trwa nasz pobyt na emigracji, tym bardziej staje się wyraźne, że największym dobrem o które tutaj dbać powinniśmy, są wartości kulturalne. Działalność kulturalna wyrasta, niezależnie od koniunktur politycznych, ze źródła najgłębszego. Źródłem tym jest wewnętrzna potrzeba człowieka, wychowanego w polskiej kulturze, manifestowania w swój własny, odrębny, swobodny sposób przeżywanych uczuć i spostrzeżeń, wypowiadania się o własnym wewnętrznym życiu, względnie o reakcji na otaczający go świat. O twórczości polskich literatów, szczęśliwie społeczeństwo polskie wie stosunkowo wiele. Na uchodźstwie wychodziło i wychodzi sporo polskich pism, kilkanaście firm

i telewizja $w$ Polsce. Zarys dziejów, (Warszawa : Elipsa, 1999); Żaneta Steffek, „Universitas" - zuryski kwartalnik Towarzystwa Przyjaciół PUNO w latach 1980-2001, (Pruszcz Gdański : Wydawnictwo Jasne, 2018); Magdalena Górka, Czasopisma edukacyjne Polskiej Macierzy Szkolnej w Londynie redagowane przez Aleksandrę Podhorodecka w latach 1970-2006, (Pruszcz Gdański : Wydawnictwo Jasne, 2019). 
wydawniczych, biblioteki, księgarnie, radio, telewizja. O wyróżnionych pracach daja znać liczne nagrody literackie. Zupełnie po macoszemu potraktowana jest plastyka polska. W samej tylko Wielkiej Brytanii pracuje kilkudziesięciu malarzy, grafików, rzeźbiarzy ${ }^{3}$ i ceramików. Niestety, po dziś dzień, za wyjątkiem kilku, którzy weszli w środowisko angielskie, maja oni bardzo ograniczone możliwości wyjścia poza ściany swoich pracowni. Większość społeczeństwa emigracyjnego żyje życiem własnym, poza środowiskiem angielskim ${ }^{4}$.

Próba zaistnienia w obcym środowisku czy asymilacji nie zawsze spotyka się z dobrym przyjęciem przez miejscową ludność. Doświadczyło tego szczególnie boleśnie pokolenie „niezłomnych”, czyli byli żołnierze Polskich Sił Zbrojnych w Wielkiej Brytanii po zakończeniu II wojny światowej. W zwiąku $z$ wynikiem referendum dotyczącego dalszego członkostwa Wielkiej Brytanii w Unii Europejskiej, które odbyło się 23 czerwca 2016 r., sytuacja kolejnych fal emigracji, w tym poakcesyjnej, też jest niełatwa. Brexit bowiem wyzwolił długo skrywaną niechęć wyspiarzy do obcych, zniknęła poprawność polityczna Brytyjczyków, ukazując w całej pełni fiasko polityki multikulti.

W tym nieprzyjaznym środowisku wyspiarzy były wydawane i nadal funkcjonują polskie czasopisma emigracyjne, które dają obraz historii niezwykłej determinacji naszych rodaków, w tym wielu kobiet, będące podmiotem naszego zainteresowania. Spośród różnych inicjatyw kulturalnych tworzonych przez Polki na obczyźnie na szczególna

3 Środowisko polskich rzeźbiarzy działających w Wielkiej Brytanii, niewielkie wprawdzie, ale połączone losem tułaczki wojennej - prawie wszyscy przeszli Syberię, łagry i więzienia rosyjskie, $z$ armia Andersa dotarli na Wyspy Brytyjskie i tu pozostali. Wspólnie wystawiaja, przeważnie w Drian Galleries i Polskim Ośrodku Społeczno-Kulturalnym w Londynie. Ich jedyna zbiorowa jak dotąd wystawa miała miejsce w POSK-u w listopadzie $1977 \mathrm{r}$. Wzięli w niej udział: Andrzej Bobrowski, Jan Marian (Marian Kościałkowski - malarz, rzeźbiarz), Jerzy Stocki, Aleksander Werner (grafik, malarz, rysownik, rzeźbiarz) i Tadeusz Zieliński (malarz, rzeźbiarz). Na ekspozycji nie było prac Adama Kossowskiego, ze względu na ich specyficzne miejsce przeznaczenia, Jana Lubelskiego (urodzony w 1922 r., studiował w Slade School w Londynie), Józefa Piwowara, Tadeusza Kopera, Jana Kępińskiego (malarz, rzeźbiarz, fotografik, filmowiec). Wszyscy polscy twórcy emigracyjni uprawiali również inne techniki plastyczne, bo z czystej sztuki rzeźbiarskiej nie mogli się utrzymać. $\mathrm{Na}$ ten temat powstały interesujacce opracowania dopiero w XX i XXI w. Vide: Jan Wiktor Sienkiewicz, Marian Bohusz-Szyszko 1901-1995, życie i twórczość, (Lublin : Wydawnictwo Katolickiego Uniwersytetu Lubelskiego, 1995); idem, Artyści Andersa. Continuita e novita, (Warszawa - Toruń, 2013; wyd. 2, Warszawa : Wydawnictwo Tako, 2014).

4 „Komunikat Zarządu Zrzeszenia Plastyków Polskich w Wielkiej Brytanii”, Kontynenty. Nowy Merkuriusz [Londyn], nr 2, 1959, 11. 
uwage zasługuje cykliczna prowokacja artystyczna, nazwana ARTeria ${ }^{5}$. Spirytus movens tych spotkań kulturalnych była Teresa Bazarnik-Małkiewicz, żona Grzegorza Małkiewicza, współwłaścicielka i współwydawca opiniotwórczego prawicowego miesięcznika nowej fali emigracji lat 80 . XX w., ukazującego się w Londynie od 2006 do 2018 r. [zostało zawieszone] - „Nowy Czas”. Ten niezależny, skierowany do inteligencji tytuł podejmuje kwestie społeczne, polityczne, naukowe, kulturalne i inne. Na jego łamach w każdym numerze odnajdujemy artykuły jej autorstwa. Zainteresowana jest przede wszystkim kwestiami najszerzej pojętej kultury, edukacji wszystkich szczebli i dziennikarstwem interwencyjno-śledczym w kontekście życia Polaków w Zjednoczonym Królestwie.

Teresa Bazarnik-Małkiewicz jest absolwentką kulturoznawstwa na Uniwersytecie Śląskim. W Polsce pracowała jako redaktor wydawnictw teatralnych w Teatrze Starym w Krakowie i Teatrze Cricot 2 Tadeusza Kantora ${ }^{7}$. Kantor zapraszał ja na spotkania $z$ wybitnymi teatrologami, reżyserami i zachodnimi dziennikarzami, czynna znajomość języka angielskiego była więc niezbędna. Jak sama stwierdziła, brak opanowania języka angielskiego był powodem jej wyjazdu na Wyspy Brytyjskie w 1990 r. ${ }^{8}$ Poczatki jej pobytu w Londynie wypełniały intensywne kursy językowe, rozmaite prace dorywcze, a wreszcie praca w redakcji londyńskiego „Dziennika Polskiego i Dziennika Żołnierza”.

W 2003 r. Grzegorz Małkiewicz został redaktorem naczelnym tego pisma. Podniósł jego poziom merytoryczny, unowocześnił stronę graficzna, powiększył grono współpracowników, mimo to został zwolniony z niejasnych przyczyn, w atmosferze skandalu. Pozwał wydawcę dziennika do sądu, ale tuż przed rozprawą wypłacono mu polubownie odszkodowanie. Ponieważ wraz z nim - na znak protestu - złożyło wymówienia kilku dziennikarzy, postanowił założyć własny periodyk. Wraz z mężem

\footnotetext{
5 O tych wydarzeniach artystycznych autorka już wspomniała w artykule pt. „Międzykulturowe inicjatywy integracyjne londyńskiego "Nowego Czasu. The New Time" w latach 2009-2013”, Media i Społeczeństwo, nr 8, 2017, 171-184; eadem, Londyński „Nowy Czas", 114-124.

6 Szerzej o tym czasopiśmie vide medioznawczą analizę: Jolanta Chwastyk-Kowalczyk, Londyński „Nowy Czas”.

7 Teresa Bazarnik, „Jak przez Wajdę o mały włos nie straciłam pracy”, Nowy Czas [dalej: NC], nr 223, 2016, 28.

8 E-mail Teresy Bazarnik do Jolanty Chwastyk-Kowalczyk, 29 V 2012, archiwum Jolanty Chwastyk-Kowalczyk.
} 
odeszła też Teresa Bazarnik-Małkiewicz i od 6 października 2006 r. zaczęli wydawać w Londynie „Nowy Czas”.

Redakcja „Nowego Czasu” dba o pozytywny wizerunek oraz utrzymywanie relacji z otoczeniem, co wpisuje się $\mathrm{w}$ działania public relations. Do najważniejszych narzędzi zewnętrznych należą międzykulturowe inicjatywy integrujące londyński periodyk $z$ odbiorcami, zwane ARTeria. Poprzez swoja działalność pozaredakcyjna jest salonem i orędownikiem kultury wysokiej. To wydarzenie artystyczne miało miejsce w latach 2009-2013. Grzegorz Małkiewicz przyznał, że:

Pomimo kryzysu, odbyły się już trzy edycje ARTerii. Ich niewatpliwym sukcesem było otwarcie sie polskiego środowiska na brytyjskich odbiorców. ARTeria, chociaż przedstawiała dorobek naszych artystów, była od początku projektem polsko-brytyjskim, co i tak jest dużym skrótem, bo narodowość tak naprawdę ma znaczenie drugorzędne, a jednocześnie decydujące o tożsamości uczestników ... ARTerią rozpoczniemy Nowy Rok 2010. Tym razem w formie zabawy - szalonej i artystycznej. Wszystkich Państwa serdecznie zapraszam ... Udział w zabawie wesprze również fundusz wydawniczy „Nowego Czasu”.

Wizytówką periodyku jest włączanie się redakcji, ale przede wszystkim Teresy Bazarnik-Małkiewicz $\mathrm{w}$ istotne przedsięwzięcia społeczne pro publico bono służące integracji Polaków w nowym kraju osiedlenia $z$ pozostałymi mieszkańcami Wysp Brytyjskich. Dzięki wspólnym wysiłkom Active Citizen Hub, Southwark Council, zajmującym się sprawami mieszkaniowymi, edukacja, integracja społeczna, i „Nowego Czasu” 18 kwietnia 2009 r. zorganizowano w Nolias Gallery przy 322 Old Kent Road pierwszy wernisaż prac artystów mieszkajacych lub pracujących w Southwark, dzielnicy Londynu, gdzie mieści się też redakcja. Spotkaniu Polaków z tej dzielnicy towarzyszyły występy polskich muzyków i śpiewaków oraz wystawa malarstwa, rzeźby i grafiki ${ }^{10}$. Władze dzielnicy zapłaciły za wynajem galerii oraz sfinansowały symboliczną lampkę wina i przekaski.

To interesujące i pożyteczne przedsięwzięcie, nazwane ARTeria, zostało przyjęte $z$ wielkim entuzjazmem, o czym świadczy ciagłość

9 Grzegorz Małkiewicz, „Na czasie”, NC, nr 20 (136), 2009, 13.

10 Teresa Bazarnik, „Chcemy poznać Polaków mieszkających lub pracujących w naszej dzielnicy”, NC, nr 6 (122), 2009, 3. 
i cykliczność imprezy - bowiem w 2013 r. odbyła się jej 15. edycja. ARTeria doczekała się też w piśmie odrębnej wkładki z sylwetkami artystów oraz reprodukcjami ich prac, pełniącej zarazem funkcję katalogu wystawy. Pierwszą zorganizowano po to, by „wyciagnąć magistrów zza zmywaków" i pozostałych rodaków pracujących poniżej swoich kwalifikacji ${ }^{11}$, jak również - by rozpropagować wiedzę o bezpłatnie rozpowszechnianym polskim periodyku „Nowy Czas”. Redakcja zachęcała: „Przyjdź, pokaż, że tu jesteś, włącz się w życie lokalnej społeczności!”. Pierwsze spotkanie zasilili swoimi pracami dojrzali artyści zaproszeni przez właścicieli pisma - Sławomir Blatton, Barbara Lautman, Krzysztof Malski, Wojciech Sobczyński, Danuta Sołowiej - mocno osadzeni na brytyjskim gruncie oraz dopiero wschodzące osobowości twórcze, czyli ci, którzy niedawno skończyli brytyjskie uczelnie artystyczne lub jeszcze studiowali: Marcin Drogosz, Marcin Dudek, Justyna Kabala, Agata Kadenacy. Spotkaniu towarzyszyły koncerty wokalno-muzyczne Anety Barciś, zespołu Giewont i Aleksandry Kwaśniewskiej ${ }^{12}$.

Należy zaznaczyć, że członkowie Association of Polish Artists in Great Britain $z$ siedzibą w Londynie odnieśli się do tego przedsięwzięcia - poza nielicznymi wyjatkami, jak przykładowo Joanna Ciechanowska, zasilająca swoim talentem plastycznym periodyk - powściagliwie. Można przypuszczać, że ich nieufność budziła możliwość bezpłatnego udziału w tym społecznym przedsięwzięciu, ponieważ w Zjednoczonym Królestwie reguła jest opłata wnoszona przez autorów za eksponowanie swoich dzieł w różnych galeriach czy na wystawach ${ }^{13}$. Żadna $z$ redakcji innych polskich czasopism ukazujacych się w Wielkiej Brytanii nie zorganizowała wcześniej podobnej cyklicznej ogólnodostępnej imprezy kulturalnej i na taką skalę.

Inicjatywa ta okazała się tak wielkim sukcesem, że kontynuowano ja do listopada 2013 r. włącznie. Te międzypokoleniowe spotkania artystów zajmujących się różnymi dziedzinami sztuki, prezentujących swoje dokonania twórcze, miały również uzmysłowić Brytyjczykom, że

\footnotetext{
${ }_{11}$ Teresa Bazarnik, Maciej Psyk, „Wyciagnąć magistrów zza zmywaków”, NC, nr 5 (5), 2006, 5 .

12 Teresa Bazarnik, "Polish Artists in Southwark", NC, nr 7 (123), 2009, 3.

13 Taka przyczynę braku zainteresowania możliwościa ekspozycji swoich prac wskazała członkini APA - artystka Joanna Ciechanowska w wywiadzie przeprowadzonym przez Jolantę Chwastyk-Kowalczyk 21 kwietnia 2016 r. w czasie zorganizowanej przez PUNO w Londynie VI Międzynarodowej Konferencji Naukowej na temat „Wkład polskich artystów i pisarzy w kulturę brytyjską po 1945 roku".
} 
nowi przybysze wnoszą niezaprzeczalną wartość do życia miasta. Każda $z$ tych prób włączania się w życie lokalnej społeczności została w „Nowym Czasie” opisana przez Teresę Bazarnik-Małkiewicz i innych dziennikarzy, publikowane były kilkustronicowe reportaże, bogato zilustrowane zdjęciami $^{14}$. Przy okazji pierwszego wernisażu wyeksponowano informację, że panneau mieszczącego się nieopodal ośrodka The Civic jest ozdobione ceramicznymi płaskorzeźbami autorstwa znanego w Wielkiej Brytanii polskiego artysty, osiadłego na Wyspach w 1942 r. w Londynie - Adama Kossowskiego (1905-1986) ${ }^{15}$. To monumentalne dzieło przedstawiajace sceny z Opowieści kanterberyjskich Chaucera twórca zrealizował na zlecenie rady miejskiej w 1966 r., o czym donosił polski dziennik emigracyjny ${ }^{16}$.

${ }_{14}$ Teresa Bazarnik, „Przyjdź, pokaż, że tu jesteś, włącz się w życie lokalnej społeczności”, NC, nr 7 (123), 2009, 3; Michał Jackiewicz, „Polscy artyści w Southwark”, NC, nr 8 (124), 2009, 1, 12-13; Wojciech Goczkowski, „Nowy czas potrzebuje nowych miejsc”, NC, nr 8 (124), 2009, 14; „Szalenie Snobistyczny Bal Artystyczny”, NC, nr 20 (1136), 2009, 32; Włodzimierz Fenrych, „ARTeria Literacka”, NC, nr 1 (137), 2010, 19; Alex Sławiński, „Balowa ARTeria”, NC, nr 2 (138), 2010, 16-17; idem, „ARTeria Poetycka”, NC, nr 4 (140), 2010, 13-15; „ARTeria \& Nowy Czas”, NC, nr 5 (141), 2010, 1, 32; „ARTeria na Wielkanoc”, NC, nr 6 (142), 2010, 1, 4-5; „ARTeria in Borough. Exhibition \& live”, NC, nr 10 (146), 2010, 1, 3-4; „ARTeria \& Nowy Czas”, NC, nr 12 (148), 2010, 1, 4-5; „The Polish Art Festival ARTeria”, NC, nr 12 (148), 2010, 32; Roma Piotrowska, „Od września do września”, NC, nr 14 (150), 2010, 3, 18; „ARTeria Andrzejki”, NC, nr 17 (153), 2010, 9; „ARTeria Andrzejki”, NC, nr 18 (154), 2010, 3; „Arteryjne Andrzejki”, NC, nr 19 (155), 2010, 16-17; “ARTeria. Music. Portrait. Personality", NC, nr 12 (169), 2011, 1, 14-16; "ARTeria. Exhibition \& Live music", NC, nr 13 (170), 2011, 2-3; “ARTeria. Poster exibition”, NC, nr 5 (182), 2012, 13-20; „Pokłosie ARTerii. Plakatowa ARTeria”, NC, nr 6 (183), 2012, 1, 13-16; Teresa Bazarnik, „ARTeria opuszcza krypty”, NC, nr 10 (196), 2013, 4-5.

15 Więcej o Adamie Kossowskim vide: "Adam Kossowski. Murals and Paintings" with contributions by Benedict Read, Tadeusz Chrzanowski, Martin Sankey, Adam Kossowski, Tymon Terlecki and Andrew Borkowski, (London : Armelle Press, 1990); "Adam Kossowski", The Burlington Magazine for Connoisseurs, Vol. 85, No. 496, 1944, 182; Jolanta Chwastyk-Kowalczyk, Londyński „Dziennik Polski i Dziennik Żotnierza” 1944-1989, 371-373; eadem, „Uniwersalny język twórczości polskich artystów plastyków na obczyźnie”, w: Magorzata Komza (red.), Świat w obrazach. Zbiory graficzne w instytucjach kultury - ich typologia, organizacja i funkcje, (Wrocław : Wydawnictwo Uniwersytetu Wrocławskiego, 2009), 115-129; eadem, „Świat bez granic... Twórczość Polaków na obczyźnie w świetle prasy emigracyjnej”, w: Adam Ilciów, Robert Potocki (red.), W kręgu polityki, (Zielona Góra Częstochowa : Śląskie Towarzystwo Naukowe im. Michała Grażyńskiego, 2009), 154-165; eadem, „Polskie czasopisma emigracyjne w Londynie - kroniką dokonań artystycznych Polaków na obczyźnie", Gospodarka. Rynek. Edukacja. Media-Kultura-Pogranicza, nr 2, 2010, 15-24; Michał Jackiewicz, „Southwark zobaczył, na co nas stać”, NC, nr 8 (124), 2009, 1, 12-13.

16 (Agn.), „Nowy sukces Adama Kossowskiego”, Dziennik Polski i Dziennik Żołnierza, nr 222 (sobotni dodatek „Tydzień Polski”, nr 38), 1966, 5. 
Kevin Dykes, przedstawiciel Southwark Council, stwierdził na przekór stereotypom:

Przedsięwzięcie takie jak wystawa w Nolias Gallery jest ważnym krokiem w kreowaniu wizerunku Polaków na Wyspach ... Stereotypy o polskich budowlańcach zabierających Anglikom pracę, czy też inne, są bardzo widoczne i dlatego ważne jest, aby polskie społeczeństwo mogło dać o sobie znać. Jeśli Anglik będzie miał możliwość poznania Polaka osobiście, być może pomyśli, że jego podejście było błędne. Być może zapoczątkuje to nowy tryb myślenia - wielu Anglików nie wie, że w Southwork jest tak duża społeczność polska. Takie wystawy jak ta mogą więc zmienić podejście do Polaków ${ }^{17}$.

To pierwsze spotkanie-wernisaż otworzyło nowe możliwości. Redaktorzy poznali artystów $z$ innych części Londynu, którzy przekonywali o konieczności podejmowania takich przedsięwzięć w innych częściach miasta, północnym czy zachodnim Londynie. W Nolias Gallery pojawił się Ray Andrews, proboszcz XVIII-wiecznego anglikańskiego kościoła St George the Martyr w Borough. Zaproponował przeniesienie wystawy do nowo oddanych po trzyletnim remoncie zabytkowych krypt swojego kościoła, położonego w jednej $z$ najstarszych dzielnic Londynu ${ }^{18}$.

Spotkanie artystyczne oraz koncerty muzyki jazzowej i folkowej odbyły się 18-19 września 2009 r. Muzyczna ARTeria - Live music i prezentacja dzieł nieformalnej grupy 19 artystów reprezentujących różne techniki, szkoły i pokolenia doczekała się dwunastostronicowej kolorowej wkładki pisma, omawiającej szczegółowo prace oraz biogramy twórców w języku polskim i angielskim ${ }^{19}$. Kolejny numer dwutygodnika uzupełnił dwujęzycznie relację z ARTerii Nowego $\mathrm{Czasu}^{20}$, nazwana przez niektórych festiwalem polskiej kultury na południowym brzegu Londynu, z której wynika, że „wystawa polskich artystów oraz towarzyszące jej koncerty zaanektowały cała przestrzeń gościnnego kościoła St George the Martyr w Borough" ${ }^{21}$. Były koncerty w kościele i w kryptach, także na zewnatrz, na tarasie przy wejściu do krypty. Artyści przejęli we władanie przykościelny ogród. Iwona Zając „nie tylko wystawiła swoje prace, ale również

17 Michał Jackiewicz, „Southwark zobaczył, na co nas stać”, 13.

18 "ARTeria in Borough", NC, nr 12 (128), 2009, 3.

19 „Muzyczna ARTeria”, nr 13 (129), NC, 2009, 1, 13-23.

20 „Relacja z ARTerii”, nr 13 (129), NC, 2009, 1-7.

${ }^{21}$ Ibidem, 1. 
tworzyła nowe”22 na oczach publiczności. Jedna z dziennikarek „Nowego Czasu” - Aleksandra Ptasińska - wyraziła przekonanie, że „to jeszcze nie koniec! ARTeria tętni życiem, w ARTerii buzuja nowe pomysły, ARTeria szykuje dla Was jeszcze wiele niespodzianek!”23.

„Nowy Czas” zaczał popularyzować w ramach kolejnej edycji ARTerii w języku angielskim polskich artystów wśród Brytyjczyków, jak na przykład mieszkającego w Zjednoczonym Królestwie współpracownika pisma Andrzeja Krauzego, zachęcając do odwiedzenia wystawy jego rysunków w krypcie kościoła St George the Martyr w Borough ${ }^{24}$. Kolejna odsłona ARTerii odbyła się 30 listopada 2009 r. i - ku zaskoczeniu organizatorów - cieszyła się dużym zainteresowaniem. Oprócz wystawy w oprawie muzycznej i wokalnej fragmenty swojej najnowszej książki zatytułowanej Czy Jahwe zastępów jest władca totalnego świata?, prezentujacej obce kultury oraz religie, przeczytał współpracownik pisma, Włodzimierz Fenrych. Motywem przewodnim tego spotkania ARTeryjnego była wystawa prac Andrzeja Krauzego. W piśmie stwierdzono, że artysta używa uniwersalnego języka symboli, czytelnego nie tylko dla Polaków, ale i dla przedstawicieli kultury anglosaskiej ${ }^{25}$.

W grudniu 2009 i styczniu 2010 r. redakcja zaprosiła czytelników na Szalenie Snobistyczny Bal Artystyczny „z udziałem artystów, prawie artystów, niby-artystów, plagiatorów, bigamistów, hochsztaplerów. Urzędnicy mile widziani”"26, który miał się odbyć 22 stycznia 2010 r. w kryptach zaprzyjaźnionego kościoła w Borough. $Z$ atmosfera Balowej ARTerii czytelnicy zapoznali się w lutym ${ }^{27}$. Okazało się, że bez szumnego nagłośnienia pojawiły się tłumy, które $z$ wielkim zainteresowaniem wysłuchały koncertu jazzowego pianisty Tomasza Żyrmonta i saksofonisty Marka Tomaszewskiego. Wydarzeniem towarzyszacym była wystawa prac Caroliny Khouri, artystki urodzonej w Libanie, wychowanej w Polsce, a mieszkającej w Wielkiej Brytanii.

Chcąc wyjść spod supremacji sztuk plastycznych i muzyki, w styczniu 2010 r. periodyk otworzył Literacką ARTerię „Nowego Czasu”,

\footnotetext{
22 Ibidem, 1.

23 Aleksandra Ptasińska, „Świeżutka relacja spod lady”, NC, nr 14 (130), 2009, 7.

24 "ARTeria presents "Andrzejki" with Andrzej Krauze”, NC, nr 16 (132), 2009, 28; „Andrzeja Krauzego portret własny", NC, nr 18 (134), 2009, 2, 15-16.

25 Alex Sławiński, „Andrzejkowa ARTeria w relacji na cztery głosy”, NC, nr 19 (135), 2009, 4.

26 „Szalenie Snobistyczny Bal Artystyczny”, 32; „Balowa ARTeria”, NC, nr 1 (137), 2010, 32 .

27 „Ach, cóż to był za bal...”, NC, nr 2 (138), 2010, 1, 16-17.
} 
ufając, że będzie inspiracją dla autorów i zachęci ich do przesyłania do redakcji wierszy, krótkich form prozatorskich bądź przekładów ${ }^{28}$. Redaktorzy przyznali, że sa niepewni losu tej nowej inicjatywy. Włodzimierz Fenrych zaprezentował własne przekłady czterech wierszy chińskiego dysydenta Guo Luszenga z grupy Szczep Poetów z Bagien Baiyang. Czytelników pisma zaproszono na wieczór poetycki z Zibą Karbassi, wschodząca gwiazda poezji perskiej, który miał się odbyć 13 lutego 2010 r. w kościele St George the Martyr w Borough. Ta poetycka odsłona ARTerii zaskoczyła uczestników multimedialnym charakterem, kiedy „mieszały się dźwięki, kolory zapachy i smaki” międzynarodowego spotkania. Publicysta Alex Sławiński wyraził opinię, że „stajemy się częścią spektaklu, który sam się reżyseruje. Przybywając na ARTerię, musimy skupić wszystkie zmysły, gdyż zasadniczy temat imprezy bywa jedynie pretekstem do tego, by przemycono i pokazano nam coś więcej"29.

$Z$ głównym tematem poetyckiego wieczoru znakomicie korespondowały specjalnie dobrane cykle obrazów Agnieszki i Tomasza Standów - wieloznaczne, nieuchwytne, skrupulatnie dopracowane, jak w poezji. Ziba Karbassi czytała swoje wiersze w języku perskim, „nikt nie rozumiał słów, ale wszyscy czuli przekaz, żywiołowy, mocny, trafiający do serca" ${ }^{\prime 3}$. Po wersji perskiej przed mikrofonem stawał Stephen Watts, który liryki Karbassi tłumaczył na angielski ekspresyjnie, dynamicznie, a po nim Włodzimierz Fenrych $z$ lirycznie melodyjna polską wersją. Ta trójjęzyczna prowokacja skłaniała do refleksji nad światem i miejscem, jakie w nim zajmuje człowiek, „stały się przyczyna, dla której Ziba jest we własnym kraju poetka na indeksie"31. Jej wiersze sa chętnie czytane i krażą w irańskim „podziemiu”. Po występie Ziby z perskim repertuarem pojawiła się Aneta Barcik z towarzyszącymi jej muzykami pochodzacymi $z$ Iranu. Po raz kolejny okazało się, że ARTeria serwuje strawę duchowa na najwyższym poziomie przez obcowanie ze sztuka, jak również z ludźmi ja tworzacymi, jednocześnie wychodzac poza polski krag kulturowy. Poetycki wieczór w St George the Martyr pokazał, że jeśli tylko się chce, łatwo można łamać bariery językowe i kulturowe, a nawet przekraczać granice dotychczas nieprzekraczalne, zrodzone przez lata nieporozumień

\footnotetext{
28 „ARTeria Literacka”, NC, nr 1 (137), 2010, 19.

29 Alex Sławiński, „ARTeria poetycka”, 13-15.

30 Ibidem, 13.

31 Ibidem, 14.
} 
i uprzedzeń, czego przykładem była prezentacja w chrześcijańskim kościele sztuki o muzułmańskich korzeniach ${ }^{32}$.

ARTeria goszcząca na łamach „Nowego Czasu” cyklicznie zachęcała czytelników do odwiedzenia różnych wystaw, którym kibicowano, jak np. fotografii ulicznej autorstwa Damiana Chrobaka, który śledzi życie Londynu od kilku już lat ${ }^{33}, 26$ marca 2010 r. w La Vista Club, czy też „Znakom Etiopii” - wystawie fotografii Ryszarda Szydly, prezentowanej w ramach St George's Festival 2 kwietnia 2010 r. ${ }^{34}$ Artysta jest członkiem Association of Polish Artists in Great Britain i miał kilka wystaw, m.in. w Royal Academy of Arts. Współpracownik pisma Alex Sławiński przeprowadził $z$ nim wywiad ${ }^{35}$. ARTeria i „Nowy Czas” zaprosiły również artystów i dzieci na Wielką Akcję Malowania Gigantycznej Pisanki w kryptach kościoła St George the Martyr 3 kwietnia 2010 r. ${ }^{36} \mathrm{~W}$ piśmie zamieszczono dwujęzyczny reportaż $z$ tego wielkanocnego happeningu, po którym zaproszono gości i uczestników do suto zastawionego wielkanocnego stołu, poświęconego przez gospodarza, anglikańskiego proboszcza, ojca Raya ${ }^{37}$.

Wrzesień był miesiącem zorganizowania kolejnej dużej, trwającej trzy dni (9-11) ARTerii: The Polish Art Festival - święta polskiej kultury nad Tamiza w kryptach i ogrodach kościoła St George the Martyr w Borough. Grzegorz Małkiewicz zauważył, że impreza ta „przykuwa coraz większą uwage opinii publicznej, owocując wielką dawką twórczej energii" ${ }^{38}$, a za największy jej sukces uznał fakt wyjścia poza polskie środowisko. Teresa Bazarnik zdała relację $z$ tych spotkań, których „niejednorodna przestrzeń plastyczno-muzyczna stała się ich specyfika”39. Tym razem gościem specjalnym był angielski wokalista i gitarzysta Jake Shaw, finalista konkursu BBC „New Talent”. Swoimi muzycznymi występami

\footnotetext{
32 Ibidem.

33 "ARTeria presents Street Photography by Damian Chrobak", NC, nr 4 (140), 2010, 28; "ARTeria presents Street Photography by Damian Chrobak", NC, nr 5 (141), 2010, 4, 28; „Nie strzelać do fotografa”, NC, nr 5 (141), 2010, 15.

34 "ARTeria presents Street Photography”, nr 5 (141), 2010, 4, 28.

35 Alex Sławiński, „Świat w obiektywie naukowca”, NC, nr 6 (142), 2010, 16; “ARTeria presents. Signs of Etiopia. A Photographic Exhibition by Ryszard Szydło", NC, nr 6 (142), 2010, 17.

36 „ARTeria \& Nowy Czas”, 1.

37 Joanna Buchta, „Znoszenie, toczenie, malowanie - czyli wielki happening w wigilię Wielkiej Nocy. Ale Jajo!!!”, NC, nr 6 (142), 2010, 4-5.

38 "ARTeria. Paintings-Photography-Sculptures-Live Music \& Gastronomia", NC, nr 10 (146), 2010, 1, 4; "The Polish Art Festival in the Crypt of St George the Martyr", NC, nr 12 (148), 2010, 32.

39 Teresa Bazarnik, „ARTeria 2010”, NC, nr 14 (150), 2010, 16-17.
} 
imprezę uświetniła również Dominika Zachman przy akompaniamencie Francuza Oli Arlotta na saksofonie i japońskiego gitarzysty Yujiro Wady. Charakterystyka muzycznej strony ARTerii jest jej wielokulturowość - ukazana dzięki zróżnicowanemu repertuarowi, osobowościom artystów ${ }^{40}$. „Grupa skupiona wokół ARTerii wywodzi się z różnych środowisk. Niektórzy z nich są w Wielkiej Brytanii od wielu lat, inni przyjechali już po przyjęciu Polski do Unii Europejskiej”"1. Z czasem muzycy zaczęli zapraszać na wspólne koncerty swoich przyjaciół z całego świata. Po latach stało się oczywiste, że spotkania te są szansą na lepsze poznanie się, przełamywanie stereotypów na trudnym brytyjskim gruncie.

W stały kalendarz ARTeryjnych spotkań wpisały się andrzejki, które w 2010 r. odbyły się 26 listopada, tradycyjnie w gościnnych kryptach kościoła St George the Martyr. Towarzyszyła im wystawa obrazów Pawła Waska, dobra muzyka w wykonaniu Agaty Rozumek, Łukasza Fiszera, J. J. Jacoba, Andrzeja Pawłowskiego oraz Jake'a Shawa, czytanie wierszy przez autorów - Annę Marię Mickiewicz, Tomasza Januszkiewicza i Adama Siemieńczyka - oraz magiczne wróżby ${ }^{42}$. Jak wspominali uczestnicy: „Atmosfera domowo-koncertowo-liryczno-niepowtarzalna; W kryptach tego wieczoru znaleźliśmy się $\mathrm{w}$ innym wymiarze; Takie spotkania sa ważne, niezbędne!; Energie zostały pobudzone; Synteza muzyki, poezji i malarstwa to jak najbardziej fantastyczny pomysł"43.

W lipcu 2011 r. powiadomiono o długo oczekiwanej edycji ARTerii, tym razem poświęconej wystawie fotograficznej, $z$ umiejętnie dobrana muzyką ilustracyjna polskich (lub mających polskie korzenie) muzyków, mieszkajacych i tworzacych w Londynie, autorstwa młodego fotografa Krystiana Daty oraz dwudniowym zaimprowizowanym jam session zaproszonych do zdjęć 22 instrumentalistów ${ }^{44}$. Drogę artystyczną Daty przybliżyła Aleksandra Ptasińska ${ }^{45}$. Potem ukazał się przewrotny tekst-manifest pt. Wyrok, w którym czytamy: „Wyrokiem polskiej społeczności maczajacej palce w prowokacjach artystycznych redakcja dwutygodnika "Nowy Czas" zostaje skazana na dożywotnie organizowanie ARTerii"

\footnotetext{
40 Ibidem, 16.

41 Roma Piotrowska, „Od września do września”, 3, 18.

42 „ARTeria andrzejki”, NC, nr 17 (153), 2010, 7; „ARTeria Andrzejki”, NC, nr 18 (154), 2010, 3.

43 Adam Siemieńczyk, „ARTeryjne andrzejki”, NC, nr 19 (155), 2010, 15-17.

44 "ARTeria, Music. Portrait. Personality. 15-16 July 2011", NC, nr 12 (169), 2011, 1, 14.

45 Aleksandra Ptasińska, „Słowiańskie trzy grosze”, NC, nr 12 (169), 2011, 15-16.

46 „Wyrok”, NC, nr 13 (170), 2011, 1, 3-5.
} 
Potwierdza to sprawozdanie $z$ udanej imprezy Sławomira Orwata, który opisał niepowtarzalna atmosferę oraz trudności $z$ jej zakończeniem, ponieważ zachwycona lawina ludzi nie chciała rozejść się do domów ${ }^{47}$.

Po dłuższej nieplanowanej nieobecności ARTeria wróciła $z$ wystawa, prezentująca historię polskiego plakatu, trwająca od 1 do 4 czerwca 2012 r. w kryptach kościoła St George the Martyr w Borough ${ }^{48}$. Było to możliwe dzięki współpracy z Galerią Plakatu w Krakowie. Wystawę uświetniły koncerty muzyki jazzowej, soulowej i rockowej. Dwujęzyczna polsko-angielska ośmiostronicowa wkładka pisma $z$ kolorowymi reprodukcjami plakatów oraz biogramami twórców tradycyjnie pełniła rolę przewodnika. Kurator wystawy Natalia Dydo opisała pokłosie tego wydarzenia artystycznego, obficie zilustrowanego zdjęciami ${ }^{49}$. „ARTeryjne plakatarium muzyczne" towarzyszące spotkaniu omówił Sławomir Orwat, podkreślając jego międzynarodowy charakter, wysoki poziom artystyczny, ciekawe występy debiutantów oraz mistrzowska interpretację standardów jazzowych ${ }^{50}$. Stwierdził z przekonaniem, że ARTeria wśród imprez kulturalnych $\mathrm{w}$ Londynie jest bezkonkurencyjna $z$ powodu niepowtarzalnego klimatu i ,jedynej w swoim rodzaju nowoczasowej atmosfery"51.

Ostatnia, 15. edycja ARTerii miała miejsce w Londynie w dniach 14-16 listopada 2013 r. Chwilowo opuściła gościnne krypty anglikańskiego kościoła, by zaistnieć multimedialnie, wielopokoleniowo i wielonarodowo w otwartym, po gruntownym remoncie, Ognisku Polskim (przy 55 Princes Gate SW 7) w Sali Hemarowskiej. Tę ARTerię, zatytułowana „Is London a Bridge?”, stworzyły prace polskich artystów różnych generacji, próbujące odpowiedzieć na pytanie, w jaki sposób Londyn wpływa na postrzeganie świata i doświadczenia polskich artystów, jak odczuwaja oni puls tego miasta i jak się w nim odnajduja ${ }^{52}$. Wybór miejsca na 15. edycję ARTerii zgrabnie ujęła publicystka Ewa Stepan: „Starzy znajomi, nowe kontakty, moje nowe i zarazem stare miejsce w Londynie - Ognisko, które nadaje sens ciagłości" ${ }^{53}$.

\footnotetext{
47 Sławomir Orwat, „Jesteśmy skazani na ARTerie”, NC, nr 13 (170), 2011, 4-5.

48 „Wystawa Polish Posters”, NC, nr 5 (182), 2012, 13-20; "Poster Exhibition”, NC, nr 5 (182), 2012, 32.

49 Natalia Dydo, „Plakatowa Arteria”, NC, nr 6 (183), 2012, 13-15.

50 Sławomir Orwat, „ARTeryjne plakatarium muzyczne”, NC, nr 6 (183), 2012, 15-16.

51 Ibidem, 16.

52 Ewa Stepan, “Ognisko. The Polish Hearth or... Heart?”, NC, nr 11 (197), 2013, 3.

53 Ibidem.
} 
Dobrym przykładem człowieka, któremu udało się zbudować London Bridge, jest malarz Paweł Wąsek, który do swej otwartej pół roku wcześniej galerii De Montage w Forest Hill zaprosił znanego rysownika, współpracującego kiedyś $z$ „The Times” i „Daily Telegraph”, a obecnie $z$ „Evening Standard”. Weef wystawił swoje prace w galerii Wąska, a jesienia obaj uczestniczyli w ARTerii ${ }^{54}$.

Także Wojciech A. Sobczyński swoim tryptykiem nawiąał do twórczości mistrza rzeźby sir Anthony'ego Caro, którego uważa za osobisty most łączący go $\mathrm{z}$ artystycznym życiem polskiej społeczności w Londynie $^{55} . Z$ kolei tytuł „Is London a Bridge?” sprowokował współpracującego $z$ redakcja "Nowego Czasu” Wojciecha Goczkowskiego, historyka sztuki, do ciekawej refleksji:

Myślę, że Londyn jest mostem, ale trochę takim zwodzonym. Raz jest, raz go nie ma. Dla niektórych jest to most, a dla innych jedynie miejsce postoju, w którym czekaja, aby ten most dla nich się otworzył. Dla innych to już miejsce osiedlenia i nie muszą przekraczać żadnych mostów. Sa i tacy, którzy przekraczaja go nieustannie w poszukiwaniu nowej drogi. Most jest zawsze jakąś obietnica. A Londyn dla wielu Polaków jest szansą i wyzwaniem, czasami niebezpiecznym, ale dającym nadzieję ${ }^{56}$.

Przypomnijmy, że celem tych cyklicznych ARTeryjnych wydarzeń była promocja polskich twórców oraz tworzenie środowiska i platformy do dialogu między artystami różnych narodowości a odbiorcą. Do takich interakcji dochodzi w wielokulturowym Londynie. Można się zgodzić z Teresą Bazarnik, że „Londyn stał się mostem łączącym początki kariery artystycznej z nowym, unikatowym doświadczeniem poszukiwania drogi na gruncie kulturowo obcym, dalekim od korzeni, fundamentów artystycznej wrażliwości i piętna rodzimej tradycji”57.

Pierwszego dnia wernisaż uświetniła skrzypaczka Barbara Dziewięcka ze swoim zespołem A Piacere Trio (Przemysław Dębski - fortepian, Anne Chauveau - wiolonczela) oraz zaproszonym akordeonista Mariuszem Miździołem. Artystka jest także członkiem orkiestry Nigela

\footnotetext{
54 Teresa Bazarnik, „ARTeria opuszcza krypty”, 4.

55 Wojciech A. Sobczyński, „W poszukiwaniu utraconego czasu”, NC, nr 11 (197), 2013, 18-19; idem, „Arteria”, NC, nr 11 (197), 2013, 5.

56 Wojciech Goczkowski, „Arteria”, NC, nr 11 (197), 2013, 4.

57 Teresa Bazarnik, „ARTeria opuszcza krypty”, 4.
} 
Kennedy'ego. W drugim dniu odbył się wieczór poetycko-muzyczny w wykonaniu studentek MA in Performance Making w Goldsmiths College in London - Tatiany Judyckiej i Dominiki Dwernickiej oraz Sebastiana Pałki, absolwenta krakowskiej PWST, który także studiuje w Goldsmiths College. Miniatura teatralna oparta na twórczości Bolesława Leśmiana w wykonaniu wielonarodowościowego zespołu zaprezentowała publiczności autora baśniowych i niebaśniowych erotyków. Wykonawcy pokazali, że zabawna dramatyzacja jego tekstów w formie performance art rzuca wyzwanie podniosłej tematyce miłości. W ostatni dzień wystapiła wokalistka, autorka tekstów i kompozycji Monika Lidke $z$ muzykami. Należy przypomnieć, że artystka zasilała swoim talentem ARTerię od pierwszej edycji w 2009 r. Ona także przekroczyła swój London Bridge, gdy przeprowadziła się do Wielkiej Brytanii z Francji, śpiewając autorskie utwory $z$ pogranicza jazzu i folku po polsku, francusku i angielsku. Zdjęcia $z$ tej ARTerii dostępne sa na stronie: Arterianowyczas.com.

Reasumujac, redakcji „Nowego Czasu” udało się w latach 20092013 jej flagowa imprezę - ARTerię - wpisać w kalendarz kulturalny Londynu. ARTerie plastyczne, muzyczne, literackie, fotograficzne, plakatowe, snobistyczne bale artystyczne były dla autorów i gości jak układ krwionośny. Dzięki nim mogli prawidłowo funkcjonować w obcej rzeczywistości, w której przyszło im mieszkać i pracować. Zostały uznane przez uczestników i gości za święto sztuki, stanowiące próbę połączenia różnych światów, przemawiających wieloma językami: malarstwem, grafika, fotografia, rzeźba, filmem, muzyka, literatura. Były prezentacja Polaków i ich gości z całego świata, mieszkających na Wyspach Brytyjskich - pokazującą reszcie społeczeństwa, że są jego integralną częścią. Były także ważnym krokiem na drodze jednoczenia Polonii, tak bardzo zróżnicowanej i nierzadko - skonfliktowanej. ARTeria połączyła również samych twórców. Setki osób przewijających się przez miejsca tych imprez zostawiły w księdze pamiątkowej wystarczający dowód na to, że warto było się spotkać. ARTeria postrzegana była jako ciagły ruch, „różność w jedności". Otwarta formuła wystaw i towarzyszacych im koncertów przyciagały również przypadkowych widzów z ulicy.

Pierwotny zamysł pomysłodawców, czyli Teresy Bazarnik i Grzegorza Małkiewicza, właścicieli „Nowego Czasu”, że pojawi się możliwość pełniejszej prezentacji środowiska artystycznego, którego aspiracje i siła wykraczaja poza granice polskiej diaspory, sprawdził się. Takie społeczne oddolne projekty jak ARTeria pokazuja, że ukrytym potencjałem 
artystycznego wydarzenia jest spotkanie, dające szansę rozmowy ludziom rozrzuconym $\mathrm{w}$ anonimowości wielkiego miasta, ludziom pochodzacym $z$ różnych regionów naszego kraju, $z$ różnych kręgów kulturowych, religijnych, narodowych, stymulujące dialog pomiędzy różnymi generacjami. Kształtująca się wokół „Nowego Czasu” grupa artystów zamanifestowała zarówno swoją obecność i potrzebę wspólnoty, jak i zdolność do refleksji. Byliśmy świadkami powstawania nie tylko zróżnicowanego i ambitnego środowiska artystów, ale również nowego miejsca otwartego na polską kulturę. Uczestnicy żywią przekonanie, że wszelkie przeszkody, głównie natury finansowej, zostana pokonane i że niejedna ARTeria przed nimi...

Można przyjąc, że ten happening artystyczny potencjalnie może przyczynić się do budowania kapitału pomostowego, zacieśniania kontaktów międzykulturowych i międzygrupowych oraz ponadgranicznych, a także do rozwoju wielokulturowych przekazów społecznych. Podczas ARTeryjnych spotkań uczestnicy i goście, nawiąując do dialogiczności, współpracowali na rzecz integracji wielokulturowej i międzykulturowej. Ich uniwersalny język czytelny jest na całym świecie.

Czasami redakcja „Nowego Czasu” obejmuje patronatem medialnym różne wydarzenia, jak np. wieczór tybetański, który odbył się 27 marca 2008 r. w kafejce InSpiral przy Camden Lock w Londynie ${ }^{58}$. Redakcja identyfikuje się ze wszystkimi ruchami wolnościowymi, stąd udział jej dziennikarza w tym przedsięwzięciu. 10\% z utargu zasiliło konto brytyjskiej organizacji Students for a Free Tibet. Przedstawiciele tej organizacji na spotkaniu poruszyli kwestie łamania praw człowieka i przedstawili losy Tybetańczyków w ich kraju okupowanym przez Chińczyków. Poza tym był koncert, filmy i prezentacje multimedialne.

Redakcja angażuje się także w rozmaite akcje społeczne, które dotyczą życia polskiej diaspory w Zjednoczonym Królestwie. Wystarczy wymienić organizowanie wieloletniej akcji protestacyjnej przeciwko sprzedaży Fawley Court na Tamiza ${ }^{59}$, Ogniska Polskiego, Polskiego Ośrodka Społeczno-Kulturalnego w Londynie czy majatku Stowarzyszenia Polskich Kombatantów. Teresa Bazarnik-Małkiewicz zdawała na bieżąco sprawozdania $z$ tych wydarzeń, pisała reportaże.

58 Marcin Piniak, „Działamy razem! Tybetański wieczór w InSpiral”, NC, nr 13 (78), 2008, 20.

59 Materiały zamieszczone na ten temat w „Nowym Czasie” wykorzystała autorka w swojej książce pt. Obraz edukacji Polaków, 44-69. 
Jednak brexit może wszystko zmienić - obywatele Zjednoczonego Królestwa w referendum 23 czerwca 2016 r. wyrazili chęć opuszczenia szeregów Unii Europejskiej, a panujące obecnie antyimigranckie nastroje nie skłaniaja do optymizmu. Trudno przewidzieć, czy nie zmienia tych wcześniej z trudem wypracowanych tendencji wspólnotowych ksenofobiczne nastroje Brytyjczyków okazywane polskim emigrantom, czego przykładem jest graffiti namalowane na ścianie budynku POSK w Londynie, nawołujące naszych rodaków do opuszczenia Wysp, rozdawanie ulotek zawierających mowę nienawiści wobec Polaków mieszkających w Cambridgeshire w środkowo-wschodniej Anglii60 oraz morderstwa dokonane na Polakach w Devon, Bolton i Harlow w 2016 r. Nie tylko dla emigrantów nastał szczególny czas na zadanie sobie pytania o własna tożsamość i miejsce na ziemi.

$Z$ opisania jednej inicjatywy tak rozległych działań dobitnie wynika, że żaden badacz w swych penetracjach naukowych polskiej diaspory na obczyźnie nie powinien pominąć czasopism emigracyjnych.

\section{Bibliografia}

\section{Opracowania}

Adam Kossowski. Murals and Paintings, with Contributions by Benedict Read, Tadeusz Chrzanowski, Martin Sankey, Adam Kossowski, Tymon Terlecki and Andrew Borkowski, (London : Armelle Press, 1990).

Adam Kossowski, „The Burlington Magazine for Connoisseurs”, vol. 85, No. 496, 1944, 182.

Chwastyk-Kowalczyk, Jolanta. Katyń, dipisi, PKPR na łamach polskich czasopism uchodźczych, (Kielce : Wydawnictwo Uniwersytetu Humanistyczno-Przyrodniczego Jana Kochanowskiego, 2011).

Chwastyk-Kowalczyk, Jolanta. Londyński „Dziennik Polski” 1940-1943, (Kielce : Wydawnictwo Akademii Świętokrzyskiej, 2005).

60 Vide np.: Tomasz Bielecki, „Pułapka brexitu”, Gazeta Wyborcza, 27.06.2016, 1; Maciej Czarnecki, „Chaos po referendum”, Gazeta Wyborcza, 27.06.2016, 12; MC, „Kto nie chce Polaków”, Gazeta Wyborcza, 27.06.2016, 12; Tomasz Bielecki, „Czy będzie praca dla Polaków w UE po brexicie”, Gazeta Wyborcza, 29.06.2016, 12-13; „Królestwo w panice”, Gazeta Wyborcza, 29.06.2016, 13. 
Chwastyk-Kowalczyk, Jolanta. Londyński „Dziennik Polski i Dziennik Żolnierza" 1944-1989. Gazeta codzienna jako środek przekazu komunikatów kulturowych, (Kielce : Wydawnictwo Uniwersytetu Humanistyczno-Przyrodniczego Jana Kochanowskiego, 2008).

Chwastyk-Kowalczyk, Jolanta. Londyński „Nowy Czas” na początku XXI wie$k u$, (Kielce : Wydawnictwo Uniwersytetu Jana Kochanowskiego, 2019).

Chwastyk-Kowalczyk, Jolanta. Londyński „Pamiętnik Literacki” - organ Zwiazku Pisarzy Polskich na Obczyźnie w latach 1976-2018, (Kielce : Wydawnictwo Uniwersytetu Jana Kochanowskiego, 2019).

Chwastyk-Kowalczyk, Jolanta. Międzykulturowe inicjatywy integracyjne londyńskiego „Nowego Czasu. New Time” w latach 2009-2013, „Media i Społeczeństwo", 2017, nr 8, 171-184.

Chwastyk-Kowalczyk, Jolanta. Obraz edukacji Polaków na obczyźnie na łamach czasopism emigracyjnych, (Kielce : Wydawnictwo Uniwersytetu Jana Kochanowskiego, 2014).

Chwastyk-Kowalczyk, Jolanta. „Polskie czasopisma emigracyjne w Londynie - kronika dokonań artystycznych Polaków na obczyźnie”, Gospodarka. Rynek. Edukacja. Media-Kultura-Pogranicza, nr 2, 2010, 15-24.

Chwastyk-Kowalczyk, Jolanta. „Swiat bez granic... Twórczość Polaków na obczyźnie w świetle prasy emigracyjnej”, w: Adam Ilciów, Robert Potocki (red.), W kręu polityki, (Zielona Góra - Częstochowa : Śląskie Towarzystwo Naukowe im. Michała Grażyńskiego, 2009), 154-165.

Chwastyk-Kowalczyk, Jolanta. „Technika i Nauka” - elitarne czasopismo Stowarzyszenia Techników Polskich w Wielkiej Brytanii, (Kielce : Wydawnictwo Uniwersytetu Jana Kochanowskiego, 2015).

Chwastyk-Kowalczyk, Jolanta. „Uniwersalny język twórczości polskich artystów plastyków na obczyźnie”, w: Małgorzata Komza (red.), Świat w obrazach. Zbiory graficzne winstytucjach kultury - ich typologia, organizacja i funkcje, (Wrocław : Wydawnictwo Uniwersytetu Wrocławskiego, 2009), 115-129.

Górka, Magdalena. Czasopisma edukacyjne Polskiej Macierzy Szkolnej w Londynie redagowane przez Aleksandre Podhorodecka w latach 1970-2006, (Pruszcz Gdański : Wydawnictwo Jasne, 2019).

Habielski, Rafał. Niezłomni i nieprzejednani. Emigracyjne „Wiadomości” i ich krag 1940-1981, (Warszawa : Państwowy Instytut Wydawniczy, 1991). 
Habielski, Rafał. „Prasa w okresie II wojny światowej. Prasa emigracyjna po 1945 roku", w: Danuta Grzelewska (red.), Prasa, radio i telewizja w Polsce. Zarys dziejów, (Warszawa : Elipsa, 1999).

Sienkiewicz, Jan Wiktor. Artyści Andersa. Continuita e novita, (Warszawa Torun, 2013; wyd. 2, Warszawa : Wydawnictwo Tako, 2014).

Sienkiewicz, Jan Wiktor. Marian Bohusz-Szyszko 1901-1995, życie i twórczość, (Lublin : Wydawnictwo Katolickiego Uniwersytetu Lubelskiego, 1995).

Steffek, Żaneta. „Universitas” - zuryski kwartalnik Towarzystwa Przyjaciót PUNO $w$ latach 1980-2001, (Pruszcz Gdański : Wydawnictwo Jasne, 2018).

\section{Artykuły prasowe}

(Agn.). „Nowy sukces Adama Kossowskiego”, Dziennik Polski i Dziennik Żołnierza, nr 222 (sobotni dodatek „Tydzień Polski”, nr 38), 1966, 5.

„Ach, cóż to był za bal...”, Nowy Czas, nr 2 (138), 2010, 1, 16-17.

„Andrzeja Krauzego portret własny”, Nowy Czas, nr 18 (134), 2009, 2, 15-16. „ARTeria \& Nowy Czas”, Nowy Czas, nr 5 (141), 2010, 1, 32.

„ARTeria \& Nowy Czas”, Nowy Czas, nr 12 (148), 2010, 1, 4-5.

„ARTeria Andrzejki”, Nowy Czas, nr 17 (153), 2010, 7, 9.

„ARTeria Andrzejki”, Nowy Czas, nr 18 (154), 2010, 3.

"ARTeria. Exhibition \& Live music", Nowy Czas, nr 13 (170), 2011, 2-3.

"ARTeria in Borough", Nowy Czas, nr 12 (128), 2009, 3.

"ARTeria in Borough. Exhibition \& live", Nowy Czas, nr 10 (146), 2010, 1, 3-4.

„ARTeria Literacka”, Nowy Czas, nr 1 (137), 2010, 19.

„ARTeria. Music. Portrait. Personality”, Nowy Czas, nr 12 (169), 2011, 1, 14-16.

"ARTeria, Music. Portrait. Personality. 15-16 July 2011", Nowy Czas, nr 12 (169), 2011, 1, 14.

„ARTeria na Wielkanoc 2010”, Nowy Czas, nr 6 (142), 2010, 1, 4-5.

"ARTeria. Paintings-Photography-Sculptures-Live Music \& Gastronomia", Nowy Czas, nr 10 (146), 2010, 1, 4.

"ARTeria. Poster exibition", Nowy Czas, nr 5 (182), 2012, 13-20. 
"ARTeria presents "Andrzejki» with Andrzej Krauze”, Nowy Czas, nr 16 (132), 2009, 28.

„ARTeria presents. Signs of Etiopia. A Photographic Exhibition by Ryszard Szydło", Nowy Czas, nr 6 (142), 2010, 17.

"ARTeria presents Street Photography by Damian Chrobak", Nowy Czas, nr 4 (140), 2010, 28.

"ARTeria presents Street Photography by Damian Chrobak", Nowy Czas, nr 5 (141), 2010, 28.

„Arteryjne Andrzejki”, Nowy Czas, nr 19 (155), 2010, 16-17.

„Balowa ARTeria”, Nowy Czas, nr 1 (137), 2010, 32.

Bazarnik, Teresa. „ARTeria 2010”, Nowy Czas, nr 14 (150), 2010, 16-17.

Bazarnik, Teresa. „ARTeria opuszcza krypty”, Nowy Czas, nr 10 (196), 2013, 4-5.

Bazarnik, Teresa. „Chcemy poznać Polaków mieszkających lub pracujących w naszej dzielnicy", Nowy Czas, nr 6 (122), 2009, 3.

Bazarnik, Teresa. „Jak przez Wajdę o mały włos nie straciłam pracy”, Nowy Czas, nr 223, 2016, 28.

Bazarnik, Teresa. "Polish Artists in Southwark", Nowy Czas, nr 7 (123), 2009, 3.

Bazarnik, Teresa, „Przyjdź, pokaż, że tu jesteś, włącz się w życie lokalnej społeczności”, Nowy Czas, nr 7 (123), 2009, 3.

Bazarnik, Teresa. Psyk, Maciej. „Wyciagnąc magistrów zza zmywaków”, Nowy Czas, nr 5 (5), 2006, 5.

Bielecki, Tomasz. „Czy będzie praca dla Polaków w UE po brexicie”, Gazeta Wyborcza, 29.06.2016, 12-13.

Bielecki, Tomasz. „Pułapka brexitu”, Gazeta Wyborcza, 27.06.2016, 1.

Buchta, Joanna. „Znoszenie, toczenie, malowanie - czyli wielki happening w wigilię Wielkiej Nocy. Ale Jajo!!!”, Nowy Czas, nr 6 (142), 2010, 4-5.

Czarnecki, Maciej. „Chaos po referendum”, Gazeta Wyborcza, 27.06.2016, 12.

Dydo, Natalia. Plakatowa Arteria, Nowy Czas, nr 6 (183), 2012, 13-15.

Fenrych, Włodzimierz. „ARTeria Literacka”, Nowy Czas, nr 1 (137), 2010, 19. Goczkowski, Wojciech. „Arteria”, Nowy Czas, nr 11 (197), 2013, 4.

Goczkowski, Wojciech. „Nowy czas potrzebuje nowych miejsc”, Nowy Czas, nr 8 (124), 2009, 14.

Jackiewicz, Michał. „Polscy artyści w Southwark”, Nowy Czas, nr 8 (124), 2009, 1, 12-13. 
Jackiewicz, Michał. „Southwark zobaczył, na co nas stać”, Nowy Czas, nr 8 (124), 2009, 1, 12-13.

„Komunikat Zarządu Zrzeszenia Plastyków Polskich w Wielkiej Brytanii”, Kontynenty. Nowy Merkuriusz [Londyn], nr 2, 1959, 11.

„Królestwo w panice”, Gazeta Wyborcza, 29.06.2016, 13.

Małkiewicz, Grzegorz. „Na czasie”, Nowy Czas, nr 20 (136), 2009, 13.

MC. „Kto nie chce Polaków”, Gazeta Wyborcza, 27.06.2016, 12.

„Muzyczna ARTeria”, Nowy Czas, nr 13 (129), 2009, 1, 13-23.

„Nie strzelać do fotografa”, Nowy Czas, nr 5 (141), 2010, 15.

Orwat, Sławomir. „ARTeryjne plakatarium muzyczne”, Nowy Czas, nr 6 (183), 2012, 15-16.

Orwat, Sławomir. „Jesteśmy skazani na ARTerie”, Nowy Czas, nr 13 (170), 2011, 4-5.

Piniak, Marcin. „Działamy razem! Tybetański wieczór w InSpiral”, Nowy Czas, nr 13 (78), 2008, 20.

Piotrowska, Roma. „Od września do września”, Nowy Czas, nr 14 (150), 2010, 3, 18.

„Pokłosie ARTerii. Plakatowa ARTeria”, Nowy Czas, nr 6 (183), 2012, 1, 13-16.

"Poster Exhibition", Nowy Czas, nr 5 (182), 2012, 32.

Ptasińska, Aleksandra. „Słowiańskie trzy grosze”, Nowy Czas, nr 12 (169), 2011, 15-16.

Ptasińska, Aleksandra. „Świeżutka relacja spod lady”, Nowy Czas, nr 14 (130), 2009, 7.

„Relacja z ARTerii”, Nowy Czas, nr 13 (129), 2009, 1-7.

Siemieńczyk, Adam. „ARTeryjne andrzejki”, Nowy Czas, nr 19 (155), 2010, $15-17$.

Sławiński, Alex. „Andrzejkowa ARTeria w relacji na cztery głosy”, Nowy Czas, nr 19 (135), 2009, 4.

Sławiński, Alex. „ARTeria Poetycka”, Nowy Czas, nr 4 (140), 2010, 13-15.

Sławiński, Alex. „Balowa ARTeria”, Nowy Czas, nr 2 (138), 2010, 16-17.

Sławiński, Alex. „Świat w obiektywie naukowca”, Nowy Czas, nr 6 (142), 2010, 16.

Sobczyński, Wojciech A. „Arteria”, Nowy Czas, nr 11 (197), 2013, 5.

Sobczyński, Wojciech A. „W poszukiwaniu utraconego czasu”, Nowy Czas, nr 11 (197), 2013, 18-19. 
Stepan, Ewa. “Ognisko. The Polish Hearth or... Heart?”, Nowy Czas, nr 11 (197), 2013, 3.

„Szalenie Snobistyczny Bal Artystyczny”, Nowy Czas, nr 20 (136), 2009, 32.

"The Polish Art Festival ARTeria", Nowy Czas, nr 12 (148), 2010, 32.

"The Polish Art Festival in the Crypt of St George the Martyr", Nowy Czas, nr 12 (148), 2010, 32.

„Wyrok”, Nowy Czas, nr 13 (170), 2011, 1, 3-5.

„Wystawa Polish Posters, Nowy Czas, nr 5 (182), 2012, 13-20.

\section{Inne}

E-mail T. Bazarnik do J. Chwastyk-Kowalczyk, 29.05.2012, archiwum Jolanty Chwastyk-Kowalczyk. 